\title{
Brazilian Labour Reform in Historical Perspective
}

\author{
Roberto Véras de Oliveira, Federal University of Paraiba, Brazil
}

\begin{abstract}
This article presents a historical perspective on the foundations of labour market regulation in Brazil. It aims to provide a better understanding of the "modernising" initiatives that have been presented since the 1990s and that have recently gained new contours with the approval of the Labour Reform, in July 2017, and other similar measures. This is particularly important because Brazil is currently suffering deep economic stagnation and a severe political crisis, after a period of significant economic growth. It draws on both classical and current studies by labour sociologists and economists, as well as on the author's previous studies.
\end{abstract}

\section{KEYWORDS}

Regulation of labour relations; flexibilisation; labour reform; trade unionism; Brazil

\section{Introduction}

This article presents an historical overview of the foundations of labour market regulation in Brazil. It seeks to provide a better understanding of the "modernising" initiatives presented since the 1990s and which recently gained new contours with the approval of the Labour Reform, in July 2017, and other similar measures.

The industrialisation of Brazil, which gained momentum in the first decades of the twentieth century, was established under a legacy of colonialism and slavery. It relied on a state structurally fragile and, paradoxically, aimed at a relentless violence against labour (Cardoso, 2010a,b). The formation of a capitalist labour market in the country thus derives from a slow and tortuous process, and acquires clearer contours only in the 1930s and 1940s, although without eradicating the marks of an odd combination between the slaver-colonial past and a late and dependent industrialising drive, whose historical consequence has been the persistent reproduction of a situation of deep social inequality (Barbosa, 2008).

The historical conditions of Brazilian labour law, with their limitations and contradictions, have led to a different pattern from that in developed countries. Since the first regulatory measures, tough disputes have taken place among businessmen, workers and state agents on the way forward. That is why the path has been tortuous. Thus, the initiatives of labour law deregulation, begun in the 1990s and resumed and intensified following the impeachment of Dilma Rousseff, as well as the resistance to them, can only be understood when this historical context is recovered, at least in broad lines.

\section{0-1945: The Initial Architecture of Labour Regulation in the Vargas Era}

The so-called Revolution of 1930, led by Getúlio Vargas, made concessions to the long-standing agrarian elite by restricting the new regulatory framework to the urban labour market. 
Consequently, it created "an irresistible utopia in an environment of great socio-economic vulnerability of the masses" (Cardoso, 2010a: 207), which induced intense urbanisation without a corresponding anchor in the process of industrialisation.

According to Santos (1987), the bases of regulation of capitalist accumulation were only established in the country after 1930, in what he called a "regulated citizenship". It was grounded on a "system of occupational stratification" rather than on a "code of political values", since only those who held occupations recognised by law were regarded as "citizens". Such regulated citizenship had several pillars: a) the regulation of professions; b) the institution of the labour record booklet (a personal document in which the terms of employment contracts and the worker's profession are registered); and c) the establishment of corporate trade unions. These unions were recognised, maintained and inspected by the state, by means of the Trade Union Charter, the Standard Statute, the Trade Union Tax, the Monopoly of the Representation by territorial basis and professional category, and the state's power to intervene in the management of trade unions at all levels.

As illustrated in Figure 1, the labour regulation system designed under the first Vargas government (1930-1945) included a broad set of institutions. These included the Ministry of Labour, the Labour Justice system, officially recognised trade unions, ${ }^{1}$ lay judges appointed by trade unions to assist the Labour Courts, Institutes of Retirement Security and Pensions (IAPs), ${ }^{2}$ the Consolidation of Labour Laws (CLT), a minimum wage, the S-System - including the National Industrial Learning System (SENAI), the National System of Commercial Learning (SENAC) and the National System of Learning in Transportation (SENAT) - among other agencies managed by corporate bodies and financed with semi-public funds.

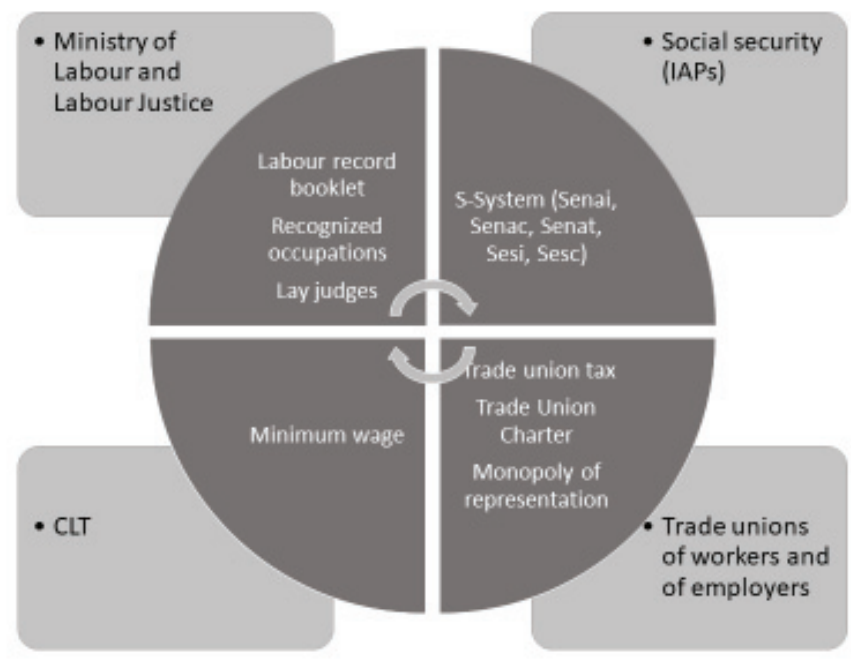

Source: elaborated by the author

Figure 1. The architecture of labour regulation in the Vargas era

\footnotetext{
${ }^{1}$ Since then, it is permissible to create trade unions, federations and confederations of both employees and employers.

2 There are many abbreviations and acronymns in this article. For the reader's convenience, we provide a list of these at the end of the article.
} 
The capitalist development process in Brazil was accompanied by a peculiar form of institutionalisation of labour relations compared to the standards adopted in developed countries. Krein (2007) notes that the economic dynamism prompted by industrialisation and the system of regulation built in the 1930s and 1940s in Brazil resulted in the gradual incorporation of an increasing share of the population into the labour market, while being unable to provide the same degree of social protection achieved in the post-war period in Europe. Structural weaknesses persisted over time, especially regarding "the structural surplus of labour force; the high turnover; the segmentation of the labour market between large companies and a significant portion of the small ones, family business and self-employment; the high informality; and low and scattered wages" (Krein, 2007: 29).

Furthermore, large segments of the working population remained excluded from the labour system, especially self-employed, rural and domestic workers (comprised mostly of women). Rural workers have been gradually incorporated since the $1960 \mathrm{~s}^{3}$ and domestic workers have recently been granted such rights, ${ }^{4}$ though still only partially.

In the Brazilian case, industrialisation came relatively late. Compared to the European and North American processes, it was marked by heavy income concentration, wage employment (growing and strong, although never reaching the extent of universalisation attained in central economies), and the social protection system (established under the protection of the state and limited in scope, and also far from being a social welfare state. These factors, illustrated in Figure 2, contributed to the constitution of a pattern of labour relations marked by social disparities, which perpetuated cleavages of social class, gender, ethnicity/race, age, region of origin and others, in both work conditions and everyday life in society.

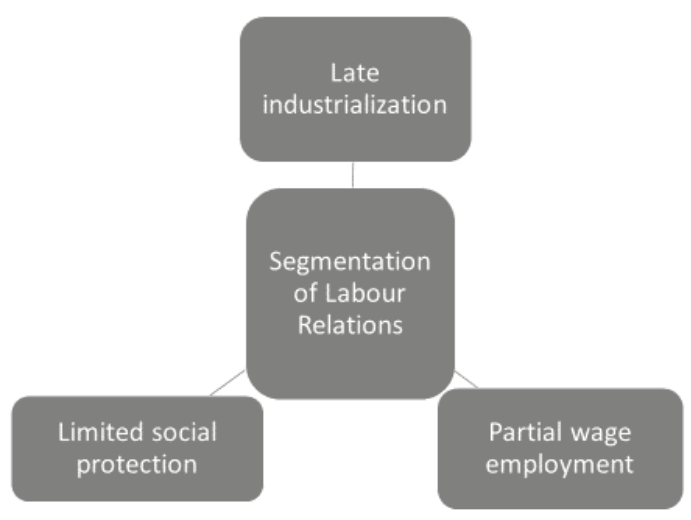

Source: elaborated by the author

Figure 2. The segmented character of labour relations in Brazil

\footnotetext{
3Particularly with the promulgation of the Statute of the Rural Worker in 1963.

${ }^{4}$ It was only in 2013 that a Constitutional Amendment was passed extending to domestic workers most of the rights that had been in force for decades for other workers (including unemployment insurance, family salary, day nursery aid and work accident insurance). However, its regulation into ordinary law took another two years.
} 
According to Cardoso (2010a), regulated citizenship turned into the institutional form of class struggle in Brazil, either in the attempt to fulfil existing rights, to extend rights to new occupations or to establish new rights. From the standpoint of workers and their representative organisations (recognised or not), such institutional arrangement inevitably became a basic standard which they either adapted to or challenged.

Thus, a complex, ambiguous and contradictory relationship emerged between the struggle for rights and the labour relations system established by Vargas. Since then, workers and their collective organisations have wavered between criticism and defence of this system.

\section{0s to 1970s: Consolidation of and Adjustments to the Vargas model}

The new industrialising drive of the 1950s, which followed the import substitution phase, was anchored on three pillars: private national capital, state capital and multinational private capital, with increasing prevalence of the latter. Hence, a clear disparity resulted between a dynamic pole, strongly integrated into the world economy and endowed with some mechanisms of social protection (named by Lipietz [1987] as "peripheral Fordist") and a wide range of subaltern productive systems based on family, artisanal, precarious, fragmented and informal enterprises. The latter comprised the great majority of the working population.

Brazilian society was living within a national-developmentalist euphoria and a climate of redemocratisation. Yet the labour system established during the Vargas dictatorship remained nearly intact.

Referring particularly to the survival of the trade union structure following the end of the "New State" (that is, the Vargas dictatorship period, 1937 to 1945), Weffort (1972) considers it surprising that it was precisely in the democratic period that the corporate trade union system was established as an instrument of the state for controlling the working class. Nevertheless, far from assuming that the trade union structure was merely an extension of the dictatorship over democracy, he states that it could also be a result of choices made by workers and trade unionists in what he calls "populist trade unionism", a kind of adherence to the "corporate system".

As noted by French (1992), however, in the democratic period between 1945 and 1964 the relationship between workers, their leaderships and the trade union structure was more complex. Notwithstanding the negative aspects of CLT, this legislation favoured the mobilisation of workers, especially at critical political moments. For Silva and Costa (2001), this was heightened by the ambivalence of the Labour Justice system, which could not always be arbitrary; otherwise it would not stand up as a legitimate power.

In this context, workers and their trade union leaders often took ambiguous positions, ranging from support to criticism. In the Constituent Assembly of 1946 there was a frustrated attempt, especially on the part of the (then newly legalised) Brazilian Communist Party (PCB), to increase trade union autonomy and freedom. Outlawed again in 1947, the PCB made an initial attempt to create "parallel" trade unions, alternatives to the official structures, an initiative that lasted from 1948 to 1952 and was subsequently abandoned (Santana, 2001).

Despite their differences, the various trade unions sought to ensure the effectiveness of social rights, to use trade union structures to legitimise the organisation of workers, and to increase trade union power by means of the so-called parallel inter-trade-union organisations (anchored, in turn, in the trade unions of the official structure). Several initiatives stand out - the establishment of the Inter-Trade-Union Unity Pact (PUI) in 1954; the Joint Action Pact (PAC) and the Pact of Unity and Action (PUA) in 1961; and the General Workers' Central (CGT) in 1962. Major struggles were organised during this period, such as the strikes of the 300000 and 
the seafarers in 1953, of the 400000 in 1957 and of the 700000 in 1963 (Santana, 2001). In the rural areas, major conflicts erupted, including those involving the Peasant Leagues in the northeast of the country (Moraes, 1970).

In the democratic interregnum (1945-1964), amid increasing trade union mobilisations and attacks from conservatives, there were no structural changes in the labour relations and trade union regulation system. No reform to the legal framework was proposed by representatives of capital, labour or the governments of the period. Still, there were occasional changes, including the following: the institution of a thirteenth salary in 1962; the recognition of the unionisation of rural workers by the Ministry of Labour in 1962; the creation of the Rural Workers Statute in 1963, which extended part of the labour legislation to rural workers; and the creation of the child allowance in 1963. During the government of João Goulart, the last of this democratic cycle and one of the most sympathetic to trade unions, a reform proposal was drafted, though it made no progress.

The military coup of 1964 changed the correlation of forces between capital and labour in favour of the former, hindering access to established individual and collective rights. Control mechanisms provided for in CLT - mainly those for political and administrative intervention in trade unions by the state, and for banning inter-trade-union organisations - were extensively mobilised. The right to strike was restricted by Law 4330, promulgated in 1964. An economic policy based on wage restraint was adopted, which met some resistance until 1968, when the dictatorship worsened. Resistance actions in the period included the creation of the Inter-TradeUnion Anti-Squeeze Movement (MIA) in São Paulo in 1967, and the strikes of factory workers of Osasco and Contagem in the same year (Weffort, 1972). The normative power of the Labour Justice system in validating collective agreements and conventions was constrained, with the government's wage policy prevailing over collective bargaining. Trade unions were compelled to take a collaborationist stance and a servicing agenda. In 1966, the National Institute of Social Security (INPS) was created, resulting from the merging of the various Institutes of Retirement Security and Pensions into a centralised social security body. In 1967, the Rural Workers' Assistance and Social Security Fund (FUNRURAL) was created, incorporating rural workers as beneficiaries of the social security system. Also in 1967, the requirement that trade unions submit agreements and conventions to the General Assembly for ratification was abolished. In the same year, the Compensation Fund for Employment Time Span (FGTS) was created, extinguishing the right to job stability. In 1975, the National Employment System (SINE) was created. In 1977, the National Institute of Social Security for Medical Assistance (INAMPS) and the Institute of Financial Administration of Social Security (IAPAS) were established.

According to Krein (2007), between the 1960s and 1970s, the economic dynamism particularly due to the so-called "Brazilian miracle" of 1967 to 1974 -allowed upward social mobility and contributed to mitigating criticism against the military regime. The government's wages policy, the repressive character of the regime, and the bureaucratic, corporatist and patronising trade union structure only started to be emphatically challenged from the second half of the 1970s.

\section{0s: The Vargas Labour System Questioned by the Left}

The impact of the struggles of workers and grassroots movements of the late 1970s and early 1980s changed the terms of political debate in the country. Moisés (1982), drawing on Weffort's (1973) criticism of pre-1964 populist trade unionism, claims that the emergence of a "new trade unionism" would have succeeded in articulating autonomous social and political demands. 
The "new trade unionism" emerged from the uprising against the dictatorship's wage squeeze policy, and against the institutional limits of the official trade unionism and the authoritarian, collaborationist and patronising practices that characterised trade union life in that period. Its central causes were the struggle for trade union freedom and autonomy, for the right to organise workers in the workplace, for the broad right to strike, and for collective bargaining (Oliveira, 2011).

However, this movement for reinvigorating trade union struggle was actually kept within the strategic limits of the scope of official trade unions, aiming primarily at winning the boards of these trade unions and then their conversion into workers' bodies of struggle. The gradual loosening of the control over the structure of trade unions in the twilight of the military regime and the beginning of re-democratisation of the country contributed once again to the criticism of the corporatist trade union model.

At the same time, there remained a significant group within the system's bureaucracy interested in keeping this model unchanged, including leaders of employers' associations and of trade union confederations, the judiciary and the ministerial bureaucracy (Almeida, 1975).

Still, the period was fertile in politicising broad popular segments of the Left. The creation of the Workers' Party (PT), the Unified Workers Confederation (CUT) and the Landless Workers Movement (MST) ${ }^{5}$ among others laid the foundations of what became known as the campo democrático e popular (democratic and popular field). Strikes broke out across various industries, involving civil servants as well as education, bank, metal, sugarcane, oil and petrochemical, and telecommunications workers. The movement Diretas Já! (Direct Elections Now!) was launched in 1984, demanding direct elections for the president of Brazil and state governors. The Constituent Assembly process was established to take place from 1986 to 1988. The CUT, together with other trade union organisations, staged six general strikes between 1983 and 1996. The country's first presidential election since the military coup of 1964 was held in 1989.

During the 1980s Brazilian society lived in a dichotomous climate of fading economic dynamism and a greatly restricted democratic transition on the one hand, and increasing grassroots organisation and social and political achievements on the other. In this context, the Constituent Assembly set up in 1986 became decisive. In spite of limitations, its achievements are undeniable. The role of the state as a provider of social services was expanded in several areas health, education, social assistance, housing, sanitation, etc. Mechanisms for involving civil society in public policy formulation, review and monitoring were introduced. The centrality ascribed to the notion of universal social rights called into question the historically constructed reference to a "regulated citizenship" (Telles and Paoli, 1998). As for labour, two groups were formed, both of them composed of left- and right-wing legislators. PT led the defence of trade union freedom and autonomy; they were accompanied in this by representatives of parties connected to traditional segments of Brazilian politics (especially those aligned with a liberal perspective) such as the Party of the Brazilian Democratic Movement (PMDB), the Liberal Party (PL) and the Liberal Front Party (PFL). On the other side, in defence of trade union unicity, ${ }^{6}$ the trade union tax, a confederation system and normative power for the Labour Justice system were the Brazilian Communist Party, the Communist Party of Brazil (PC do B), the Labour Democratic Party (PDT) - parties of the Left, although more centrally positioned - as well as

\footnotetext{
${ }^{5}$ Created respectively in 1980, 1983 and 1984.

${ }^{6}$ The term "trade union unicity" derived from the principle of the monopoly of representation, provided for in Brazilian trade union legislation. It is, therefore, a formal unicity imposed by law, a situation that generated controversy among trade unionists about its benefits for workers' organisation.
} 
most of the representatives of the traditional and conservative parties, jointly named by the media as Centrão (the Big Centre).

The new Constitution was enacted in 1988, establishing new bases for labour regulation in the country. It incorporated unprecedented new social and political advances (as shown in Figure 3): the constitutionalisation of social and labour rights already provided for in the CLT and in existing collective agreements (maternity and paternity leave, vacation pay, thirteenth salary, FGTS, etc.); the regulation of unemployment insurance, created in 1986; recognition of the right to strike and to unionisation for civil servants; representation of workers in companies with more than 200 employees; the elimination of mechanisms for governmental intervention in trade unions; and greater freedom of organisation, collective bargaining and trade union elections. This framework was complemented by the constitution of a universalised social security system, based on the Unified Health System (SUS) and on the Social Security and Social Assistance System (SUAS). On the other hand, limitations remained in some aspects, including labour issues. Some of the approved rights have been subject to subsequent regulation, such as the right to strike (especially for civil servants) and the right to organise in the workplace. The monopoly of representation, the compulsory trade union tax and the normative power of the Labour Justice system were preserved, thus constituting a hybrid model of trade union regulation.

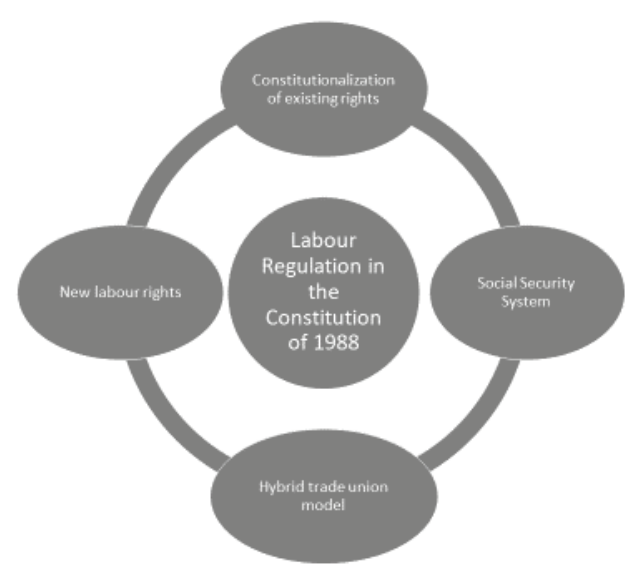

Source: elaborated by the author

Figure 3. The 1988 Constitution and the new bases of labour regulation

Shortly after its promulgation, the 1988 Constitution was criticised by the Left for its shortcomings - a stance that was reversed when attacks came from the Right during the 1990s. The neo-liberal wave established thereafter was guided by business and government discourses of excessive labour costs and the need to increase flexibility of labour relations.

\section{0s: The (Modified) Vargas Labour System Questioned by the Right}

The 1989 presidential election in which Fernando Collor and Lula da Silva competed for the presidency presented two diametrically opposed projects. One was neo-liberal, in line with world trends following the Washington Consensus. The other was democratic and popular, representing the grassroots achievements amassed throughout the 1980s. Collor was victorious, 
inaugurating an openly pro-market agenda in the country, to the detriment of the public regulation of labour relations.

The agenda of industrial restructuring, privatisation and administrative reform of the state, among other processes, entailed unemployment, flexibilisation, informalisation and precariousness of employment (Pochmann, 2009). Initially, the economic recession and the ideologically conservative assault - pro-market and hostile to citizenship rights - combined with growing unemployment rates, entailed a demobilisation of workers and the adoption of a defensive agenda by trade unions (Oliveira, 2011).

Despite some attempts to advance labour reform, the Collor government could not fulfil its promises because he was impeached in 1992. A more favourable context was created during the administration of Itamar Franco, and some labour and trade union reforms were negotiated. A national circuit of debates that took place in 1993, sponsored by the Ministry of Labour, helped to make clear the positions of strategic actors in the sphere of labour regulation (Oliveira, 2002). As shown in Figure 4, three main positions were established.
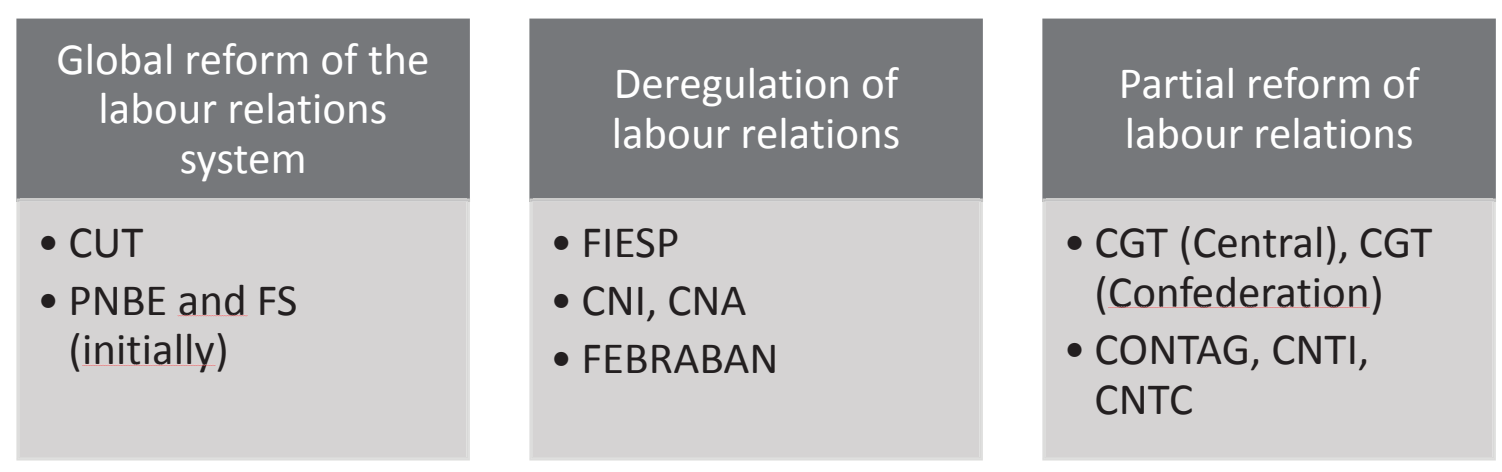

Source: elaborated by the author

Figure 4. Main positions on labour regulation in the early 1990s

The CUT, Força Sindical (FS, then the second largest trade union confederation) and the National Think Tank of Entrepreneurs (PNBE) called for a global reform of the labour relations system, including the implementation of a new labour code. The aim was the democratisation of labour relations, with trade union freedom and autonomy, and the adoption of legislation to safeguard trade union organisation and collective bargaining, based on International Labour Organization (ILO) conventions and recommendations. Such measures were meant to be accompanied by ruling out trade union unicity and the trade union tax, as well as the normative power of the Labour Justice system. However, the increasing hegemony of the neo-liberal discourse, the weaknesses of the PNBE's business leadership and the wavering positions of Força Sindical, which started to support measures of flexibilisation of labour relations, undermined this perspective.

The major business organisations - such as the Federation of Industry of the State of São Paulo (FIESP), the National Confederation of Industry (CNI), the National Confederation of Agriculture (CNA) and the National Federation of Banks (FEBRABAN) - took a stance in defence of the deregulation of labour relations. They defended the supremacy of "free 
negotiations" by each company, without any safeguard legislation, in which negotiation should prevail over what was provided for in law. On the other hand, they generally defended the maintenance of trade union unicity, the confederate system and the normative power of the Labour Justice system.

A third group advocated a partial reform of labour relations. This group included representatives of workers' organisations (as well as some business associations) identified with the confederate system - the General Workers' Central (CGT-Central), the General Confederation of Workers (CGT-Confederation), the National Confederation of Industrial Workers (CNTI), the National Confederation of Workers in Commerce (CNTC), the National Confederation of Agricultural Workers (CONTAG) and the business association National Confederation of Transport (CNT). The defence of trade union unicity, compulsory contributions, normative power for the Labour Justice system, lay judges, a confederate system and CLT prevailed.

The government of Henrique Cardoso, strongly backed by the media, chose to halt the tripartite institutional dialogue and to promote the deregulation of labour rights. The strategy was to make sporadic although systematic changes in order to face less resistance. Cardoso often made use of medidas provisórias ${ }^{7}(\mathrm{MPs})$. Those who opposed deregulation were put on the defensive, both the groups that proposed global reform and those that advocated a partial reform of the labour relations system. At the end of the period, the adopted measures had strongly affected flexibilisation of labour relations, entailing loss of rights.

The main MPs on labour regulation issued by Cardoso (and their year of issue) were: exemption of the employment relationship between cooperatives and their associates (1994); revocation of wage policy based on the automatic indexation of wages to inflation (1995); regulation of profit sharing, making wages variable (1995); weakening of labour law enforcement mechanisms (1995); anti-trade-union government stance (1995); withdrawal from ILO Convention 158 (on dismissal without a valid reason) (1995); liberalisation of work on Sundays in the retail trade (1997); revocation of the single legal regime for civil servants (1998); nullification of the principle of indefinite validity of collective agreements, requiring their annual renewal (1998); creation of fixed-term contracts of up to twenty-four months (1998); regulation of parttime work of up to twenty-five hours a week, with a proportional reduction of salary and leave (1998); institution of a "Bank of Hours", 8 to be established by collective bargaining for all types of activities (1998); suspension of the individual employment contract for a period of two to five months, accompanied by a professional qualification course (1998); abolition of lay judges in the Labour Justice system (1999); creation of balanced bipartite Pre-Conciliation Commissions aimed at promoting extrajudicial conciliation through private mediation (2000) (Krein, 2007). There were also attempts to change the law on strikes, the way in which the confederation system was funded, and the organisation of the Labour Justice system. Still, some measures, although being scattered initiatives, led to the expansion of rights: the regulation of unemployment insurance; the limits imposed on child and adolescent labour; the incorporation of paid frequent overtime into the advance notice compensation; the prohibition of discrimination based on sex and race; and

\footnotetext{
7 These decrees are issued as a matter of urgency by the President of the Republic, with immediate force of law, but they must later be approved by the Congress.

8 The Bank of Hours is a way of dealing with overtime, the terms of which are generally decided through collective bargaining. The company keeps count of overtime hours for each employee, which it later repays with time off rather than with overtime pay. The aim is to make the working day more flexible and productive without incurring substantial overtime costs for the employer.
} 
more favourable rules for maternity leave. In the last year of the Cardoso administration, the President presented a bill proposing to amend article 618 of the CLT with a provision for privileging negotiated terms over the legislated ones, in order to avoid using a constitutional amendment to carry out a structural change in the CLT. This bill was approved in the Chamber of Deputies in 2001 but did not reach the Senate.

Summing up the period, the process of flexibilisation and labour precarisation advanced during this time (see Figure 5). Business managers became motivated or compelled to start restructuring production focusing on job flexibility, especially through outsourcing. They lobbied for changes in law and mobilised the media to legitimise this process and associate it with demands for deregulation of labour relations. The governments of the period, firmly backed by other institutional powers and the media, acted in favour of deregulation and flexibilisation of labour relations. They fostered industrial restructuring and changed labour laws, leading to privatisation and reform of the state. They took an anti-trade union stance and criminalised social movements. Furthermore, they adopted a macroeconomic policy dissociated from the horizon of employment. The decline in economic dynamism resulting from the previous conditions was accompanied by a downward trend in employment and labour income indicators (degree of formalisation, wage levels, quantitative and qualitative results of collective bargaining, among others). The confluence of all this produced an extremely unfavourable environment for workers. What was left to trade unionism was defensive action and resistance in order to deal with an adverse economic environment, an unfavourable political environment, an anti-trade-union stance, initiatives for labour precarisation by employers, and new conditions of operation more adverse to collective action. All this contributed to overcoming the corporatist trade union structure and to politically reconciling internal differences. Even so, trade unionism has remained as a reference for workers' demands in collective bargaining and before the judiciary, as well as in the context of more general political dialogues with the Executive and Parliament, although with a performance clearly lower than in the previous period.

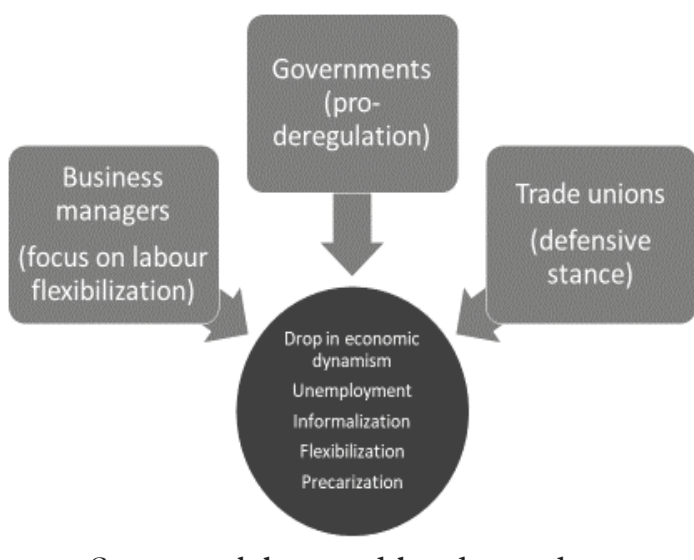

Source: elaborated by the author

Figure 5. The 1990s: tendency to flexibilisation of labour relations 


\section{3-2015: An Interregnum in the Trend of Labour Flexibilisation in Brazil?}

The Lula and Dilma governments represented a promise; they symbolised the democratic and popular field. During their tenure, the government's programme focused on social justice, production and development; the resumption of the national project signalled a counterpoint to neo-liberalism. They took a stance between conflicting interests, incorporating demands from different sectors of society - from the social and trade union movements; from the new environmental movements; from business segments in defence of production in the face of the financialisation of the economy; they also made room for the demands of financial capital and rent-seeking. Furthermore, as coalition governments, they yielded to the pressures of clientelistic politicians (all the more significant as such governments have been forced to expand their parliamentary support base).

Regarding the labour issues, the first action by the government was to withdraw the bill proposed by Cardoso government, which was pending approval by the Senate (see above). In 2003, the National Labour Forum (FNT) was created, aimed at favouring social negotiation, as well as the National Economic and Social Development Council (CDES), the National Bureau for Collective Bargaining for federal civil servants, the National Social Security Forum, and ministerial conferences in the areas of labour and employment, health, education, environment and cities, among others.

The FNT was established with a balanced tripartite composition, gathering representatives of government, workers and employers (Oliveira, 2008). The government took a stance between the historical commitments of its core - the PT and trade unions - and the commitments made to its allied base. Business representatives sought to achieve their agenda of flexibilisation of labour legislation. Different stances persisted among the trade union confederations on labour and trade union issues, while a convergence base was built. Among trade union representations, a position of greater resistance to flexibilisation prevailed, even in the case of the FS. Once the Forum was in place, debates started focusing on the Trade Union Reform project, through proposals from the confederations and with the support of the government.

The following were the main agreements reached by the National Labour Forum on Trade Union Reform: the establishment of collective contracts for all sectors of the economy; the legalisation of the trade union confederations; trade union organisation by branch of economic activity (rather than by professional category); the end of the official trade union tax; replacement of the monopoly of representation with a more participatory and pluralistic system of trade union recognition; reduction of the normative power of the Labour Justice system; expansion of the right to strike; creation of the National Council of Labour Relations as the highest body of labour regulation in the country.

There were areas of disagreement as well: the principle of trade union freedom and autonomy versus trade union unicity; the level of centralisation and national coordination of collective bargaining and whether there was need for safeguard legislation; extinction or reformulation of the normative power of the Labour Justice system; the measure of required guarantees for the right to strike, and for organisation by workplace.

Although not the ideal proposal intended by trade union centrals, they later defended the final text of the Trade Union Reform as a step forward. Resistance to the project came mainly from the business community and from right-wing parties, whether those in the supporting base of the PT government or with the opposition. Adding to such resistance, the political crisis began in 2005-2006, triggered by a broad media campaign of allegations of corruption (which became 
known as mensalão) involving the nucleus of government. This interrupted the proceedings of the project in the Congress, and the Forum ceased to function.

In 2008, the government negotiated with the trade union centrals a bill proposing their recognition. The bill also commissioned them to elaborate and coordinate the general action policies of their affiliated trade unions and to act on behalf of workers generally, with a representation proportional to their membership, in the various tripartite arenas for discussion of subjects of general interest to the workers. To this end, the centrals had to meet minimum representativeness requirements. Once recognised, they would qualify to receive 10 per cent of the total trade union tax collected from workers (Araújo and Oliveira, 2011).

Since 2004, positive changes in the labour market, with the reduction of unemployment rates and the creation of formal jobs, pointed to a more favourable scenario for workers and trade union action. The greater articulation between trade union centrals and the government resulted in the creation of a quadripartite commission - comprising government, workers, employers and retirees. It developed a permanent policy of minimum wage readjustment, which was approved by the Congress in 2008. The minimum wage increased significantly after 2005.

Despite their limitations, the Lula and Dilma governments brought about marked improvements in the conditions of workers and in income distribution in the country, supported by the real appreciation of the minimum wage (Baltar et al., 2010).

However, despite a more favourable environment for workers, labour flexibilisation measures continued, although at a slower pace and sporadically (Krein and Biavaschi, 2015). Several measures stand out: the bankruptcy law approved in 2005 (which reduced workers' privilege in payment of labour liabilities in case of bankruptcy); the pension reform in the public sector (which, among other measures, extinguished the Single Legal Regime for civil servants); the first-employment programme (created in 2003), which introduced special conditions for hiring young people without the full guarantees of labour law; the creation of Super Simples (2006), which provided differentiated conditions for micro-enterprises regarding tax and labour obligations (also creating more precarious hiring regimes); labour permits on Sundays and holidays for trade workers, conditional on ratification in collective bargaining agreements (2007). Labour flexibilisation also continued to advance through the dynamics of the labour market, with the spread of outsourcing and informality, the hiring of workers through B2B contracts, ${ }^{9}$ and non-compliance with labour legislation, combined with the high turnover in employment and the increasingly favourable stance of the Labour Justice system towards flexibilisation.

Figure 6 sums up the period (compared to the previous context illustrated by Figure 5). While both workers and trade unionism attained some gains, some measures of labour law flexibilisation continued, even if not to the same extent or at the same pace. Regarding the matters of labour and social protection, both governments acted within limits and ambivalences. Among other initiatives: they eluded the labour reforms demanded by the business representatives; adopted an economic policy to impel growth, expansion of the domestic market and employment generation; developed social policies focused on income transfer and the reconstitution of the minimum wage; opened up new arenas for social negotiation; and incorporated trade unionists into strategic public management posts. They also adopted some flexibilising measures, such as the first-employment contract and the law of Super Simple. One hypothesis is that, even while seeking greater wage and social gains for the workers, the

\footnotetext{
${ }_{9} \mathrm{~B} 2 \mathrm{~B}$, or business-to-business, refers to a situation where one company carries out a business transaction with another - for example, buying something that it needs to make its product. Companies may use this approach (converting wage contracts into B2B contracts) to avoid or reduce labour costs.
} 
governments of that period found it difficult to take their proposals further because of the obstacles created by their own allies. The government initiatives in favour of social and citizenship rights have always been resisted by other institutional powers and by the media, but also by segments of their own base of support in Parliament. Thus employment indicators reacted positively: unemployment rates fell, employment formalisation grew, workers' average income rose and collective bargaining results improved, favouring trade union action. Companies continued to implement outsourcing and labour flexibilisation (and to push for their regulation on a favourable basis), although they have become more cautious in view of the political environment and of some recovery of trade union bargaining power. Trade unionism was favoured by the general improvement of the labour market, as well as by a better transit within the federal government (except for the segments opposed to the government). This has improved its effectiveness in collective bargaining and overall political influence, although it did not regain the political prominence that it had in the 1980s, since it has not been able to obtain greater labour gains from the PT governments, nor to exercise a more effective counterpoint to the employers.

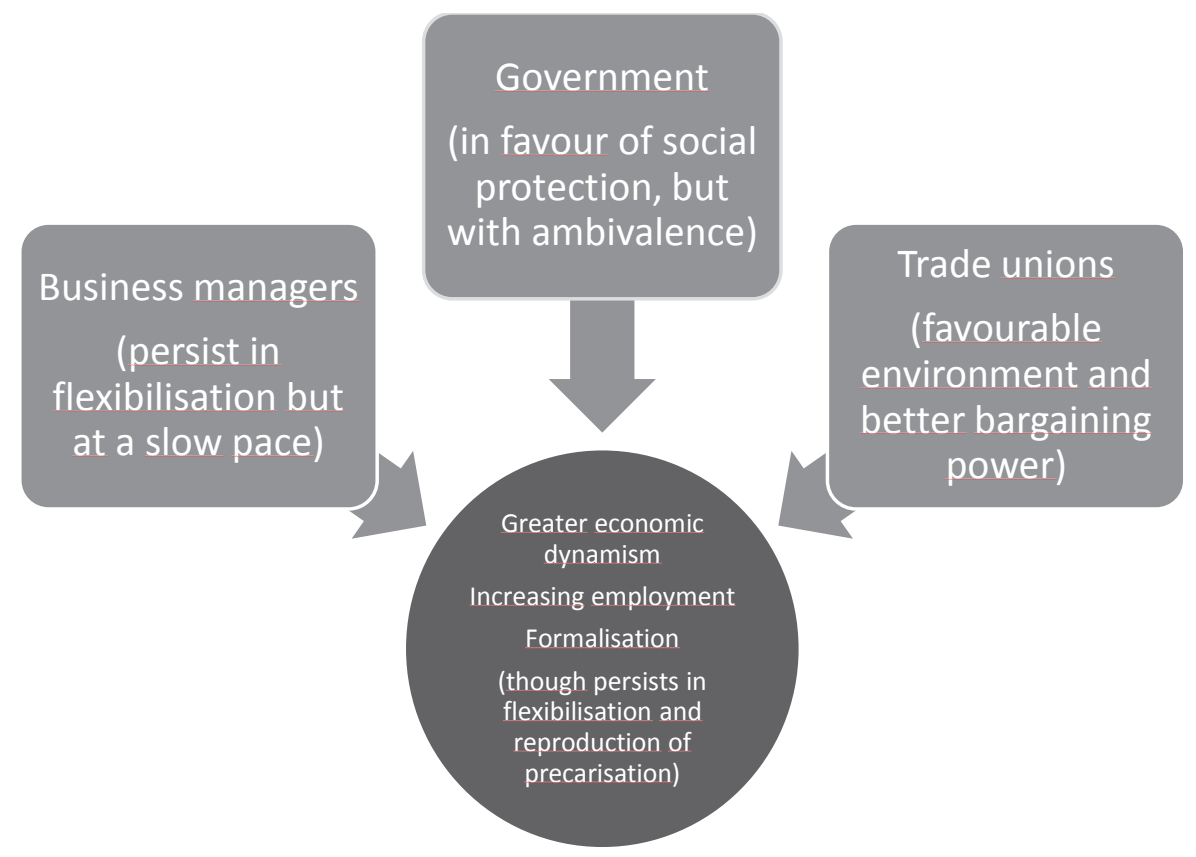

Source: elaborated by the author

Figure 6. Labour's gains, 2003-2015

\section{The New Old Times: Are Setbacks Inevitable?}

The policies of the Lula and Dilma governments were aimed at economic development with income distribution. They were unable to substantially change the general conditions of a labour market that carries the historical marks of segmentation, inequality, structural surplus, flexibility, turnover, widespread infringement of labour laws, and a high rate of informality. On the whole, however, they achieved unquestionable social and political advances.

This context eventually began to change. Some social processes have converged over the 
years to create a conservative wave, especially since 2013. These processes include: a systematic media campaign against Lula, Dilma, the PT and the Left's ideas, seeking to associate them with corruption; the growth of new evangelical charismatic churches and their political representatives; the advance of a discourse endorsing repression, by the media and other social agents, in response to the increase of daily violence and popular struggles; the spread of conservative and fascist attitudes among middle-class groups; the dissemination of a meritocratic, moralistic, conservative, anti-PT and anti-Left stance among state corporations (Oliveira, 2017).

A sequence of events (increasingly interconnected) marked a shift in the correlation of forces, in favour of a conservative, backward, anti-democratic discourse and towards the resumption of neo-liberal policies. These events included: the mensalão scandal (2005 and 2006 ); the beginning of the slowdown of the Brazilian economy (2012), mainly due to the fall in the international price of commodities and the exhaustion of the mechanisms adopted by the government to boost domestic income and consumption; and the demonstrations in June 2013, which revealed the government's political weariness vis-à-vis its militant base and the encouragement of conservative middle-class segments to speak out publicly. Despite resulting in the fourth consecutive victory of PT candidates (twice with Lula and twice with Dilma), the presidential election of 2014 was won by an extremely tight margin and under strong polarisation and tension.

Once sworn in, Dilma took fiscal adjustment measures, aiming to contain growing pressures from the Right against her government. However, these measures not only failed but they also aggravated the situation, causing her to lose support on the Left. The government became overly fragile and suffered a media-parliamentary-judicial coup, led by the Vice-President Michel Temer. The economy went into recession and unemployment exploded. Pressures rose from various sectors: from the market for increased fiscal austerity and alienation of public assets; from businessmen for labour, social security and tax reforms; from the parliamentary bases that had backed the coup for larger shares of the federal budget and implementation of an agenda of social, political, environmental and cultural setbacks; from state corporations for more power and privileges.

A new scene emerged, now unambiguous (see Figure 7). The pressures of the new hegemonic forces converged towards an aggressive agenda of deregulation of labour and social rights. In order to remain in power, the Temer government had to set up a bargaining desk to meet the demands of large economic groups as well as conservative and backward political forces. The approval of the [public expenditure] "ceiling law", ${ }^{10}$ the outsourcing law ${ }^{11}$ and the Labour Reform, coupled with the announced pension reform, have already launched the biggest reversal in acquired social rights in the history of the country. The main targets are the rights guaranteed in the CLT and in the 1988 Constitution, and the benefits that came with the social policies of the Lula and Dilma governments. As for trade unionism, it has lost governmental support in favour of employment and workers' income, and there is now an economic environment unfavourable to employment and bargaining. Trade unions can no longer count on a certain caution by companies against damaging workers' rights. This means that unions must

10 Adopted in 2016, this was one of the most harmful measures in terms of negative social effects. Proposed as a constitutional amendment, it established a ceiling on the readjustment of annual public expenditure for a period of twenty years, linked to inflation rates. This will affect health, education and other social policies. If such a ceiling is not met, even the readjustment of the minimum wage may be banned.

${ }_{11}$ In March 2017, the Chamber of Deputies approved a bill authorising outsourcing in all economic sectors, for both core and non-core activities, including in the public sector. 
play a more proactive role in carrying out a political agenda based on labour rights, at the risk of succumbing to the ongoing conservative avalanche.

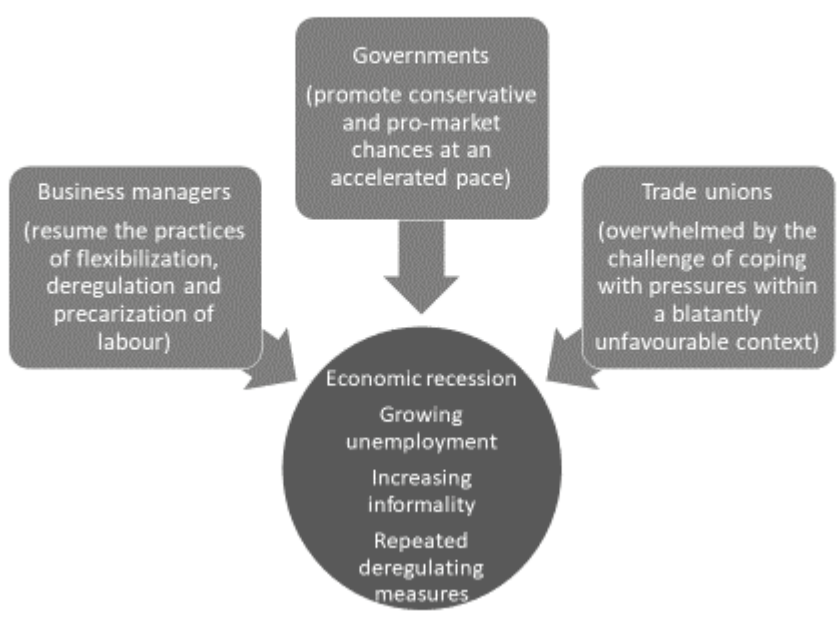

Source: elaborated by the author

Figure 7. Post-coup: the setback agenda

\section{The Labour Reform of the Temer Era}

One of the first measures of the Temer government was, at the end of 2016, to send a bill on Labour Reform to Congress. This was developed with strategic advice from business entities, particularly FIESP and CNI, and therefore it was fully consistent with the demands of companies.

Before the Labour Reform was enacted, in March 2017 the new government promoted the approval of the outsourcing law, which authorised outsourcing in "core activities". At the same time, the Labour Reform bill was referred to the Special Committee of the Chamber of Deputies for analysis; it received 457 amendments. At an accelerated pace, without discussion with society, and with the media reporting just the arguments in favour of the bill, the Committee's final report incorporated changes to more than one hundred CLT clauses. In April, the bill was approved by the Chamber with 296 votes in favour and 177 against, and in July it was approved in the Senate with 50 votes to 26, without any change to the text approved in the Chamber. Shortly thereafter, it was promulgated by the president and entered into force on 11 November 2017.

In this context, the new impetus towards flexibilisation and deregulation of labour relations, with the Labour Reform as the flagship, is systematically defended in business, media and governmental discourses under the euphemism of "modernisation". This movement blatantly points to a return to a pattern of labour relations similar in several of its aspects to that generally prevalent before the introduction of modern forms of regulation represented by CLT. ${ }^{12}$

\footnotetext{
12 Well-known labour market researchers with a conservative profile took a stance in favour of the Labour Reform. An emblematic example was the statement by Hélio Zylberstajn, a professor at the Department of Economics of the University of São Paulo, in a thematic session in the Senate. On that occasion he
} 
The current Labour Reform represents the greatest change ever made to the foundations of the Vargas system. According to the Centro de Estudos Sindicais (CESIT, 2017), its main pillars are:

a) the primacy of the negotiated over the legislated - it weakens and subordinates the role of the legal system, especially in terms of social protection, and prioritises "free negotiations" that can lead to a waiver of legal rights;

b) the subversion of the CLT - which despite its limits has established a standard of protection of labour relations in the country;

c) the weakening of the role of the Labour Justice system - which historically has worked in the Brazilian context, albeit with many limitations, as a balancing mechanism between capital and labour in a relationship that is asymmetric and unequal;

d) the legalisation of different types of contract - instead of referring to the historical standard of an integral employment contract, of indefinite duration and endowed with social guarantees, the so-called "atypical" contracts are recognised in their various forms (either through legal regulations or through collective bargaining);

e) the replacement of state intervention in the resolution of labour disputes with the notion of compromise between parties - thus depleting the public mechanisms of conflict resolution powers;

f) the weakening of trade union organisation - by eliminating the main source of financing for most trade unions (trade union tax has ceased to be compulsory and is deducted from a worker's salary only if authorised by the employee), thus undermining their collective bargaining power and the means of taking trade union legal actions to the Labour Justice system.

CESIT (2017) anticipates a variety of consequences following the implementation of the new labour reforms. These include the dissemination of atypical and precarious forms of hiring (outsourcing, intermittent employment, part-time or temporary contracts, independent contractor, home office and negotiation of dismissal, among others). There will also be greater flexibilisation of working time, lowering of average remuneration, changes in health and safety standards to the detriment of workers, weakening of trade unions and collective bargaining, and restriction of workers' access to the Labour Courts, which have also been weakened.

In reaction to those measures, members of Labour Justice system - judges, prosecutors and lawyers, articulated around the Association of Labour Magistrates (ANAMATRA) - threaten not to apply the new rules, on the grounds that they violate rights provided for in the Constitution and in international conventions. On the other hand, the trade union centrals have tried to outline some resistance, such as the convening of a National Day of Mobilisation in Defence of Rights on 10 November 2017, the day before the new law was due to be implemented.

pointed out aspects of the Labour Reform that he believes can be used to strengthen negotiations between companies and workers. Among them, he cited the prevalence of the negotiated over the legislated. For economists, the measure is an important innovation because it will create opportunities for mutual gains (https://www12.senado.leg.br/noticias/videos/2017/05/helio-zylberstajn-afirma-quereforma-trabalhista-traz-aspectos-importantes-para-a-negociacao). However, the subject has been very controversial among researchers. Publications such as CESIT (2017) and Krein, Gimenez and Santos (2018) bring a systematically critical view of the Labour Reform from the perspectives of economists, sociologists and legal professionals; they represent an example of the dispute in the academic field. 
Unfortunately, this action did not attain much support. ${ }^{13}$ On the other hand, under the headline "Brazilian labour reform discourages investors in the USA", Folha de São Paulo published a report on 3 October 2017 about a meeting of the Brazil-US Chamber of Commerce, in which US businessmen complained about the timidity of the Labour Reform approved in Brazil. As for the government, not only did it not veto any provisions in the approved law of reform (although having promised senators who hesitated to support the Chamber-approved bill to do so), but it also proceeded with its agenda of dismantling public regulation of labour. On the one hand, the Ministry of Labour issued a decree on 16 October 2016 establishing new rules for the characterisation of slave-like work conditions, as well as for updating the record of employers who have submitted people to this condition (known as the "black list of slave labour"). On the other hand, the government's support base in the Chamber of Deputies intends to approve a bill aimed at extinguishing the Labour Justice system, in order to avoid the creation within it of an area of resistance to the implementation of the approved law.

\section{Conclusion}

Even with many restrictions, Brazil has historically built the pillars of the public regulation of labour relations, which has been providing a certain level of social protection for workers for decades. Since its introduction in the 1930s and 1940s, the system of labour regulation has incorporated new achievements, including the enactment of the 1988 Constitution, with the advance of democratic forces and the fall of the military regime established in 1964. Between the 1930s and the late 1980s, the social protection system increased its coverage as new rights were incorporated, although with conflicts and restrictions. During this period, trade unions have had to adapt to the political conditions of each moment - sometimes under dictatorial regimes, sometimes under a more democratic environment. They aimed at gaining more rights, at the expansion of public benefits, and at the removal or mitigation of state control on workers and the union struggle.

From the beginning of the 1990s, a neo-liberal agenda was imposed and the system of labour regulation began to be pressured by businessmen and governments towards more and more flexibility in labour relations. At that time, trade unionism assumed a defensive agenda, prioritising the struggle for the preservation of jobs and workers' rights, as well as guaranteeing the freedom of trade union action.

As for the PT governments, they created an unprecedented situation, with economic growth and improvement of social and labour indicators. However, the convergence of government and trade unions to the preservation of social rights was not enough to reverse the historical conditions of precarious work and contemporary pressures to make labour regulation more flexible, resulting in precarious employment. The social gains of this period show that the implementation of a neo-liberal agenda of labour law deregulation is not an inevitable process. This political experience also indicated that such counterpoints were not sufficient to prevent some flexibilising measures, to guarantee structural changes and, above all, to avoid a new liberal-

\footnotetext{
${ }_{13}$ Despite a certain degree of unity among the various trade union centrals in opposing the Labour Reform, there are also divergences between them. These relate to the degree of (in)tolerance to flexibilisation of labour protection, or to differences regarding the strategies to be adopted, with more or less willingness to negotiate with the government. For instance, comparing the positions of the CUT and the FS, the former was more willing to refuse all the proposals and less willing to negotiate with the government (considered as illegitimate), while the FS was more open to negotiation.
} 
conservative wave, which has been putting on the scene one of the most retrograde official agendas since the 1930s. Probably the correlation of forces that underpinned these progressive governments was not enough to go further in social achievements.

The current measures - with an emphasis on outsourcing law and labour reform - are intended to further increase the correlation of forces that, since the coup of 2016, have favoured a conservative, neo-liberal and retrograde perspective. It is not only an adjustment between a new form of regulation of labour relations and employer practices that point to the flexibilisation and precariousness of work. The measures that have been taken point to the greatest social setback in the country's history. This places a heavy burden on trade unionism, which has to react simultaneously to the attack on workers' rights and the basic guarantees for trade union action.

The current electoral process, which tends to polarise the dispute between left-wing and right-wing projects, is marked by institutional instability and unpredictable results. It will certainly play a decisive role in the way forward. It may present a chance to sectors committed to the rights of workers to resume and increase the gains brought during the PT governments.

\section{REFERENCES}

Almeida, M.H.T. (1975) Sindicato no Brasil: Novos Problemas, Velhas Estruturas. Debate e Crítica, 6(1): $32-60$.

Araújo, A. and R.V. Oliveira (2011) El Sindicalismo Brasileño en la Era de Lula. Revista Latinoamericana de Estudios del Trabajo, 5(1): 83-112.

Baltar, P., A.L. dos Santos, J.D. Krein, E. Leone, M.W. Proni, A. Moretto, A.G. Maia and C. Salas (2010) Moving Towards Decent Work. Labour in The Lula Government: Reflections On Recent Brazilian Experience. Global Labour University Working Papers, 9(1): 1-43.

Barbosa, A. (2008) A Formação do Mercado de Trabalbo no Brasil. São Paulo: Alameda.

Cardoso, A. (2010a) A Construção da Sociedade do Trabalho no Brasil. Rio de Janeiro: FGV.

Cardoso, A. (2010b) Uma Utopia Brasileira: Vargas e a Construção do Estado de Bem-Estar numa Sociedade Estruturalmente Desigual. Dados, 53(4): 775-819.

Centro de Estudos Sindicais (CESIT) (2017) Contribuição Crítica à Reforma Trabalhista. Campinas: Unicamp. https://www.eco.unicamp.br/images/arquivos/Dossie14set2017.pdf (accessed August 2017).

French, J. (1992) The Brazilian Workers' ABC: Class Conflict and Alliances in Modern São Paulo. Chapel Hill: University of North Carolina Press.

Krein, D. (2007) Tendências recentes nas relações de emprego no Brasil - 1990/2005. Doctoral thesis in Economics, UNICAMP, Campinas, Brazil.

Krein, D. and M. Biavaschi, M. (2015) Brasil: os Movimentos Contraditórios da Regulação do Trabalho dos Anos 2000. Cuadernos del CENDES, 1(1): 47-83.

Krein, D., D.M. Gimenez and A.L. Santos (eds.) (2018) Dimensões críticas da Reforma Trabalbista no Brasil. Campinas: UNICAMP/IE/CESIT.

Lipietz, A. (1987) Mirages and Miracles (Crises in Global Fordism). London: Verso.

Moisés, J.A. (1982) Qual é a Estratégia do Novo Sindicalismo? In Alternativas Populares de Democracia: Brasil Anos 80, edited by J.A. Moisés. São Paulo: Vozes/CEDEC.

Moraes, C. (1970) Peasant Leagues in Brazil. In Agrarian Problems and Peasant Movements in Latin America, edited by R. Stavenhagen. New York: Doubleday.

Oliveira, M.A. (2002) Política Trabalhista e Relações de Trabalho no Brasil: da Era Vargas ao Governo FHC, Campinas. Doctoral thesis, IE/Unicamp, Campinas, Brazil. 
Oliveira, R.V. (2008) A Reforma Trabalhista e a Concertação Social no Brasil In A Questão Social no Novo Milênio, edited by E. Estanque, H. Costa, M.J. Canelo, A. Casimiro and R. Bebiano. Revista Travessias, 6/7(1): 391-411.

Oliveira, R.V. (2011) Sindicalismo e Democracia no Brasil: do Novo Sindicalismo ao Sindicato Cidadão. São Paulo: Annablume.

Oliveira, R. V. (2017) Precarious Work, Development and the Social Question in Brazil: A Tortuous and Difficult Path. Análise [Friedrich-Ebert-Stiftung], 25(1): 1-26.

Pochmann, M. (2009) What Brazil Learned from Labour Flexibilization in the 1990s. International Labour Review, 148(1): 269-282.

Santana, M.A. (2001) Homens Partidos: Comunistas e Sindicatos no Brasil. São Paulo: Boitempo.

Santos, W.G. (1987) Cidadania e Justiça: a Política Social na Ordem Brasileira. Second edition. Rio de Janeiro: Editora Campus.

Silva, F.T. and H. Costa (2001) Trabalhadores Urbanos e Populismo: Um Balanço dos Estudos Recentes. In O Populismo e sua História: Debate e Crítica, edited by J. Ferreira. Rio de Janeiro: Civilização Brasileira.

Telles, V.S. and M.C. Paoli (1998) Social Rights: Conflicts and Negotiations in Contemporary Brazil. In Cultures of Politics/Politics of Cultures: Revisioning Latin American Social Movements, edited by E. Dagnino. A. Escobar and S. Alvarez. Boulder: Westview Press.

Weffort, F. (1972) Participação e Conflito Industrial: Contagem e Osasco - 1968. Cadernos CEBRAP, 5(1): 1-93.

Weffort, F. (1973) Origens do Sindicalismo Populista no Brasil. São Paulo: Estudos Cebrap.

\section{ACRONYMS AND ABBREVIATIONS}

ANAMATRA
CDES
CESIT
CGT-Confederation
CGT-Central
CLT
CNA
CNI
CNT
CNTC
CNTI
CONTAG
CUT
FEBRABAN
FGTS
FIESP
FNT
FS
FUNRURAL
IAP
IAPAS
ILO
INAMPS
INPS
MIA
MP
MST
PAC

Association of Labour Magistrates

National Economic and Social Development Council

Centro de Estudos Sindicais

General Confederation of Workers

General Workers' Central

Consolidation of Labour Laws

National Confederation of Agriculture

National Confederation of Industry

National Confederation of Transport

National Confederation of Workers in Commerce

National Confederation of Industrial Workers

National Confederation of Agricultural Workers

Unified Workers Confederation

National Federation of Banks

Compensation Fund for Employment Time Span

Federation of Industry of the State of São Paulo

National Labour Forum

Força Sindical

Rural Workers' Assistance and Social Security Fund

Institute of Retirement Security and Pensions

Institute of Financial Administration of Social Security

International Labour Organization

National Institute of Social Security for Medical Assistance

National Institute of Social Security

Inter-Trade-Union Anti-Squeeze Movement

Medidas Provisórias

Landless Workers Movement

Joint Action Pact 


$\begin{array}{ll}\text { PCB } & \text { Brazilian Communist Party } \\ \text { PC do B } & \text { Communist Party of Brazil } \\ \text { PDT } & \text { Labour Democratic Party } \\ \text { PFL } & \text { Liberal Front Party } \\ \text { PL } & \text { Liberal Party } \\ \text { PMDB } & \text { Party of the Brazilian Democratic Movement } \\ \text { PNBE } & \text { National Think Tank of Entrepreneurs } \\ \text { PT } & \text { Workers' Party } \\ \text { PUA } & \text { Pact of Unity and Action } \\ \text { PUI } & \text { Inter-Trade-Union Unity Pact } \\ \text { SENAC } & \text { National System of Commercial Learning } \\ \text { SENAI } & \text { National Industrial Learning System } \\ \text { SENAT } & \text { National System of Learning in Transportation } \\ \text { SINE } & \text { National Employment System } \\ \text { SUAS } & \text { Social Security and Social Assistance System } \\ \text { SUS } & \text { Unified Health System }\end{array}$

\section{BIOGRAPHICAL NOTE}

Roberto Véras de Oliveira is an Associate Professor of Sociology in the Department of Social Sciences and Graduate Program in Sociology at the Federal University of Paraíba. He holds a PhD in Sociology from the University of São Paulo and was a visiting scholar in the Institute for Research on Labor and the Development at the University of California, Los Angeles. Professor Véras de Oliveira is also a researcher of the Brazilian National Council for Scientific and Technological Development, with a productivity grant from the same institution. His main study fields are: labour unions and social protest; labour relations; informal work; vocational training; public policy on work; employment and income; and social economy. [Email: Roberto Véras de Oliveira roberto.veras.2002@gmail.com] 